\title{
Status of a Limonium binervosum agg. (Plumbaginaceae) segregant in an Anglesey saltmarsh
}

\author{
E. Ivor S. Rees \\ Menai Bridge, Anglesey, Wales
}

\section{Corresponding Author: ivorerees@hotmail.com}

This pdf constitutes the Version of Record published on $28^{\text {th }}$ February 2022

\begin{abstract}
A distinctive segregant of Limonium binervosum agg. (G.E. Sm) C.E. Salmon (Plumbaginaceae) has been known in sandy saltmarshes near Rhosneigr, Anglesey (v.c.52), since at least 2006. Based on morphological characters it belongs in the $L$. recurvum (sensu lato) part of the aggregate, but it differs from the only $L$. recurvum subspecies previously confirmed as present on Irish Sea coasts, L. recurvum subsp. humile (Girard) Ingrouille. This was renamed $L$. naniforme (Ingr) Sell due to Sell \& Murrell (2018), treating subspecies of $L$. binervosum agg. as full species. If a consensus adopts this approach, it leaves the Anglesey $L$. recurvum (sensu lato) segregant without a valid name. Under the hierarchical system propounded by Ingrouille \& Stace (1986), the Anglesey plants are named here as $L$. recurvum subsp. crigyllensis I. Rees subsp. nov (Crigyll Sea-lavender).
\end{abstract}

Keywords: new micro-endemic; sandy saltmarsh; Crigyll Estuary; Irish Sea

\section{Introduction}

A Rock Sea-lavender Limonium binervosum agg. (G.E. Sm) C.E. Salmon

(Plumbaginacae), readily distinguishable in the field from others of this aggregate at the same locality, was noticed in 2006 as quite frequent in the sandy saltmarshes of the Afon Crigyll estuary, near Rhosneigr, Anglesey, (v.c.52) (Rees, 2010). The most obvious features were the rough, zig-zag, flowering stems (scapes) and a compact clump growth form (Fig. 1). They were identified at the time as L. recurvum C.E. Salmon (Irish Sea-lavender) based mainly on information given by Stace (1997). Four subspecies and six varieties of this taxon had been recognised by Ingrouille \& Stace (1986), but the ones in Anglesey could not confidently be ascribed to any of these micro-taxa. An added reason for caution was that the micro-taxa of $L$. binervosum agg. are agamospermous, often resulting in the development of local micro-endemic forms. The nearest records to Anglesey then shown in the BSBI database of any of the named $L$. recurvum micro-taxa (sensu Ingrouille \& Stace, 1986), were of $L$. recurvum subsp. humile (Girard) Ingrouille. This occurs on the Mull of Galloway, Wigtownshire (v.c.74) and at St. Bees, Cumbria (v.c.70). Both localities are about $160 \mathrm{~km}$ from Anglesey across the North Irish Sea and in cliff or scree habitats rather than sandy saltmarshes. Other British \& Irish L. recurvum infraspecies, as reviewed by Ingrouille \& Stace (1986), all occur much further away, 
including at Portland Bill, Dorset v.c.9, the type locality for L. recurvum C.E. Salmon (sensu stricto) and at several disjunct localities with their own subspecies or varieties on the west and north coasts of Ireland.

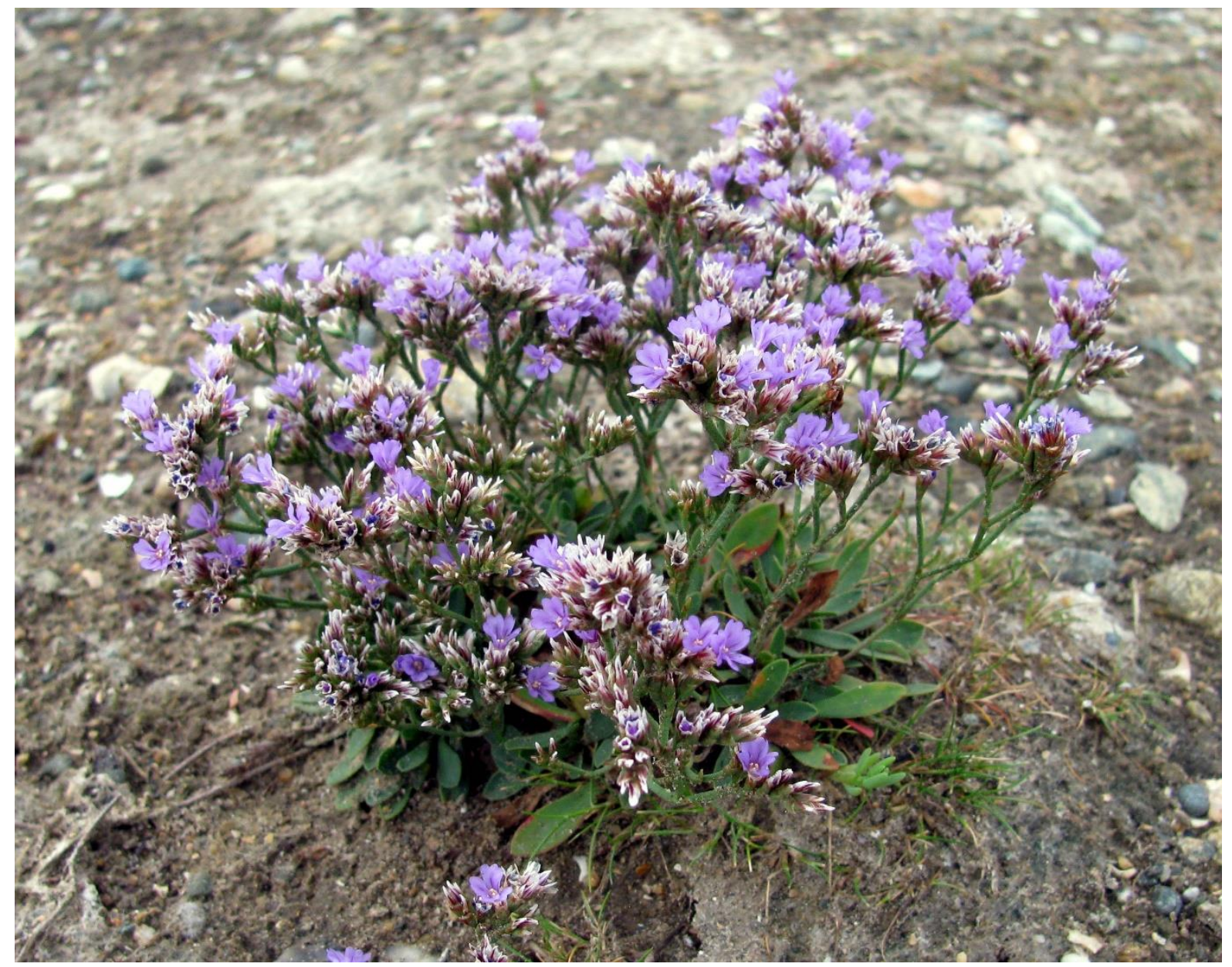

Figure 1. Limonium recurvum subsp. crigyllensis forming a compact multi-rosette clump on open sandy gravel in the Crigyll Estuary, Anglesey v.c.52, National Grid monad SH3174, 01/08/2013.

Twelve years after the initial identification of the Crigyll Estuary plants as belonging with $L$. recurvum (sensu lato) micro-taxa, significant changes were made to L. binervosum agg. taxonomy by Sell \& Murrell (2018). This was a consequence of P. D. Sell treating the previous micro-taxa as full species. As the Crigyll Estuary plants differ from those at the Mull of Galloway or, based on descriptions both by Ingrouille \& Stace (1986) and Sell \& Murrell (2018), from any other L. recurvum subspecies / species in Britain \& Ireland, they would cease to have a valid name other than inclusion in the L. binervosum aggregate. As Sell's approach has yet to be fully adopted, the Crigyll segregant is named here as L. recurvum subsp. crigyllensis I. Rees subsp. nov (Crigyll Sea-lavender). It is named after the small estuary of the Afon Crigyll where it is endemic. The spelling used here is "crig", appropriately meaning creek in Welsh, as on the OS Explorer map (2010 revision), but Jones (1989), discussing the derivations of river names on Anglesey, considers "crug" should be the spelling for the river, probably referring to a mound or cromlech. 


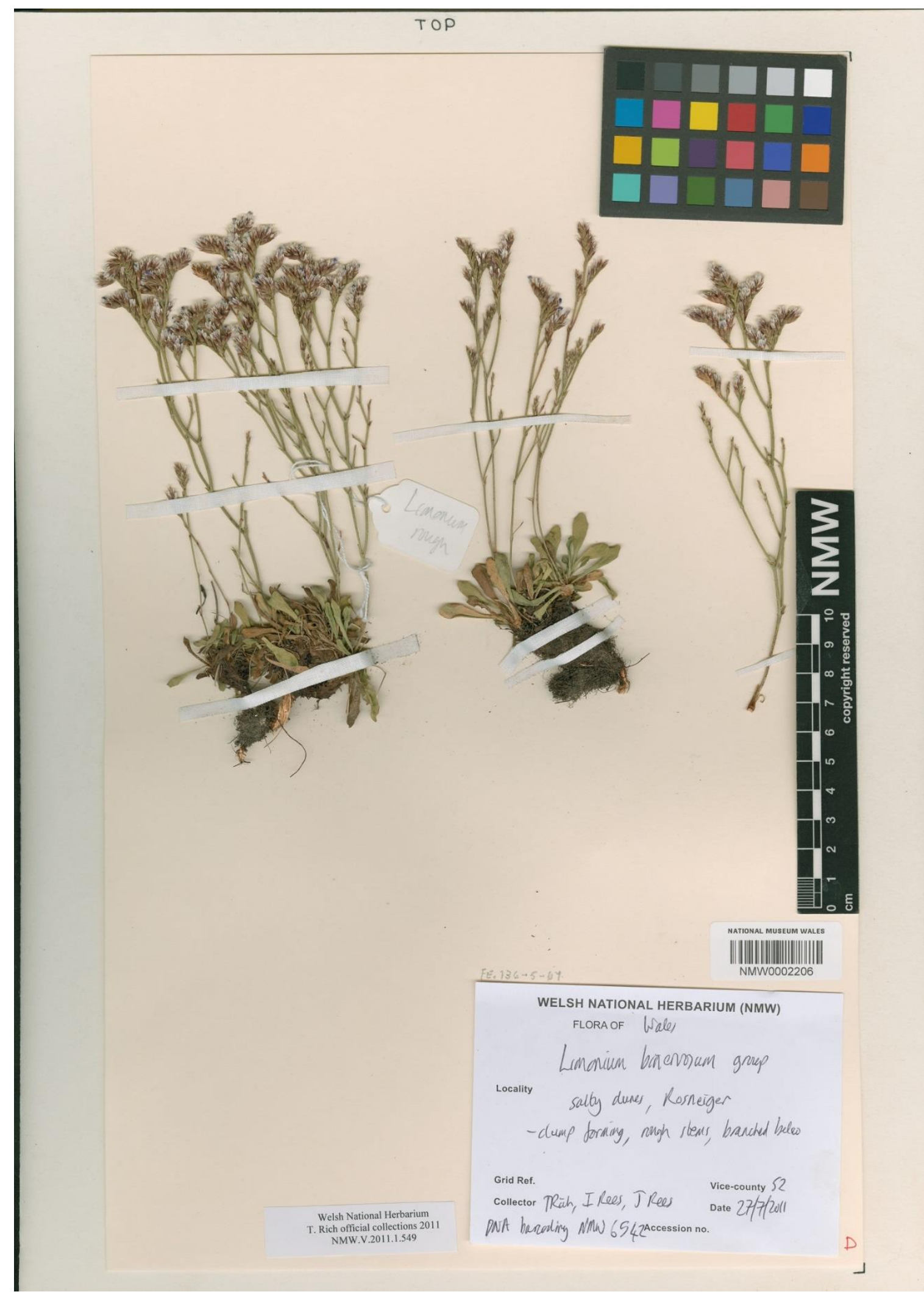

Figure 2. Scan of the holotype (left) of Limonium recurvum subsp. crigyllensis in the National Museum of Wales. Collected by T. Rich, I. Rees \& J. Rees from the Crigyll Estuary, Rhosneigr 27/07/2011. 


\section{Taxonomic treatment}

Limonium recurvum subsp. crigyllensis $\mathrm{I}$. Rees subsp. nov

Holotype: Sandy saltmarsh, Afon Crigyll estuary, Rhosneigr, Anglesey (v.c.52).

SH3174, 27/07/2011, coll. T. Rich, I. Rees \& J. Rees. NMW. V.2011.1.549. NMW image. 0002206. (Fig. 2).

Basal rosettes congested. Leaves oblanceolate, lacking prominent salt glands, lateral veins barely visible or absent. Scape height $13-14(20) \mathrm{cm}$, verrucose to base when mature and fresh, roughness lost when dried. Scape strongly zig-zagged, branches sterile in lower $1 / 3$, flowering spikes in upper $1 / 3$. Principal spikelets $10-20 \mathrm{~mm}$, recurving distally, many with supplementary branch at base. Outer bracts progressively obscuring more of inner. Calyx tube ribs aristate.

\section{Characteristics}

The Crigyll Estuary rough (verrucose) scape plants, named here as L. recurvum subsp. crigyllensis, mainly occur as compact clumps with multiple very densely packed rosettes. Many of the flowering stems are so closely spaced that they seem to entangle, resulting in the flower spikes lying close together (Fig. 3). Due to this the clumps have an overall appearance from a distance that differs from the more diffuse spike spacing typical of L. procerum (C.E. Salmon) Ingr. (Tall Sea-lavender), which is frequent at the same site. Some isolated rosettes putting up single rough scapes can also be found.
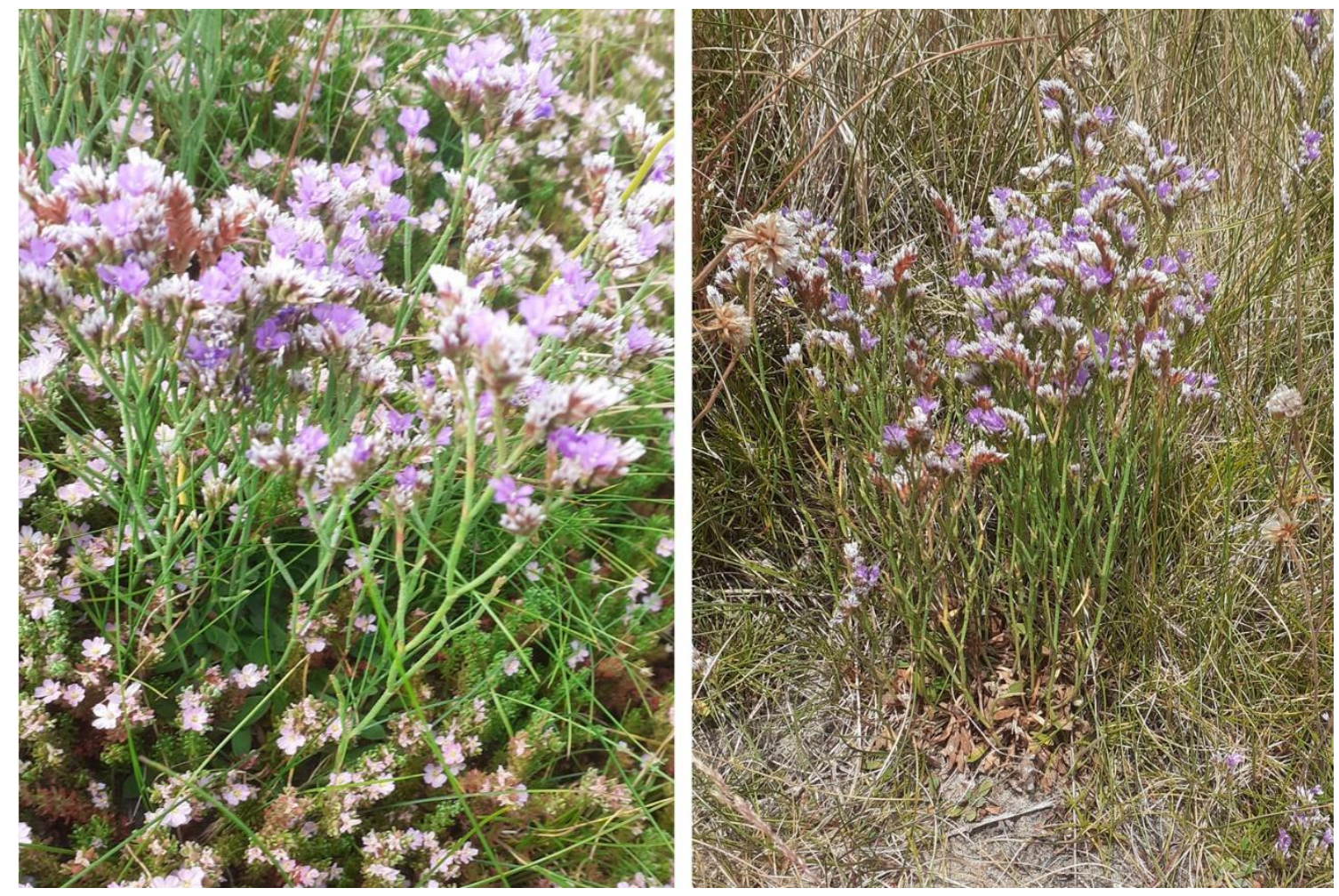

Figure 3. Left: clump of Limonium recurvum subsp. crigyllensis partly overwhelmed by spread of Frankenia laevis (Sea Heath) with rosette leaves largely obscured, 24/07/2021. Right: clump in taller grasses, under drought conditions, with most rosette leaves dead, 24/07/2021. 
The basal rosette leaves are erect where the petioles emerge, often remaining obliquely erect where rosettes are congested. Leaf shape is oblanceolate with the petiole part about equal in length to the lamina. Relative petiole and lamina dimensions vary and are imprecise as the parts intergrade. Larger leaves reach lengths of $40-50 \mathrm{~mm}$, with the lamina 6-8 $\mathrm{mm}$ wide. The apex of the leaf is usually obtuse. The leaves have distinct hyaline margins and small mucros are present on some. They do not show the obvious salt glands visible on some other $L$. binervosum agg. micro-species. The lateral veins are very faint and not visible at all on many leaves. In this the Crigyll plants diverge from the description given by Ingrouille \& Stace (1986) for the species L. recurvum, as characteristically having " 3 obvious parallel veins". Instead, they more closely fit the descriptions by Sell \& Murrell (2018) for the West of Ireland and North Irish Sea taxa which had been treated as subspecies and varieties of $L$. recurvum by Ingrouille \& Stace (1986). In their introduction to the genus, Sell \& Murrell (2018) commented that some differences in accounts might be partly due to Ingrouille's descriptions being based mainly on plants that were greenhouse grown from field cuttings, while Sell based his accounts mainly on herbarium or wild material. In drought conditions, as in July 2021, rosette leaves of some clumps shrivel (Fig. 3, right), but normally most remain until the following year.

Scapes arise from under the current rosettes. Heights are typically $13-14 \mathrm{~cm}$ with some $>20 \mathrm{~cm}$ when growing amongst other vegetation and the stem diameter $1.0 \mathrm{~mm}$. First branching is usually at $<1 / 4$ of the total height and the first branch is sterile. The sterile branches themselves often branch. Branches two and three may also be sterile or nearly so, with spikes at the tips with just one or two barely formed spikelets. Only a very few isolated single rosette (young?) plants have scapes that are short and unbranched below. The scale leaf at the first node on the scape is about $5.5 \mathrm{~mm}$ long and acute. At flowering these scales are green with red/brown in the distal parts. The flowering spikes are all in the top $1 / 3$ of the scape height. Branching angles are about $30-35^{\circ}$ above the first branching node. Stems strongly zigzag with the branches continuing at an orientation roughly aligned with the stem below, while the stem above the node deviates. A few plants also have short branches in some axils. These are sterile or end in very small spikes with few spikelets. In situ and when fresh the scapes, including their lowest sections, obviously feel rough. Roughness is less pronounced on the scapes before the terminal spikes fully develop. Salt glands are visible under magnification and sand grains are sometimes found sticking to them. The scapes shrink to become corrugated as they dry and the verrucose character becomes less apparent within 2 days of collection. This superficial succulence around a stiff core may partly explain why Ingrouille \& Stace (1986) found roughness to be an important character, which was emphasised in keys, while Sell \& Murrell (2018), relying more on herbarium material, put less emphasis on roughness in their descriptions while usually mentioning the relative abundance of salt glands.

Principal flowering spikes are 10-20 mm long, with dense spikelets at 5-7 per $\mathrm{cm}$, but other shorter spikes carrying only a few spikelets are also often present 
below the terminal spikes. The larger terminal spikes recurve distally when fully developed (Fig. 4, left). There is sometimes also a smaller spike that is on such a short branch that it appears to be part of the terminal spike (Fig. 4, right). On some of these terminal spikes, where a first spikelet would be expected to develop, the additional short spike branches off with just 2-3 spikelets on it. Sometimes this additional spike has a single outer bract subtending the small group of spikelets. Extra branching at or close to the base of principal spikes was not specifically mentioned by Ingrouille \& Stace (1986) for any taxon, but this feature was shown by them on drawings of $L$. recurvum subsp. recurvum from Portland.

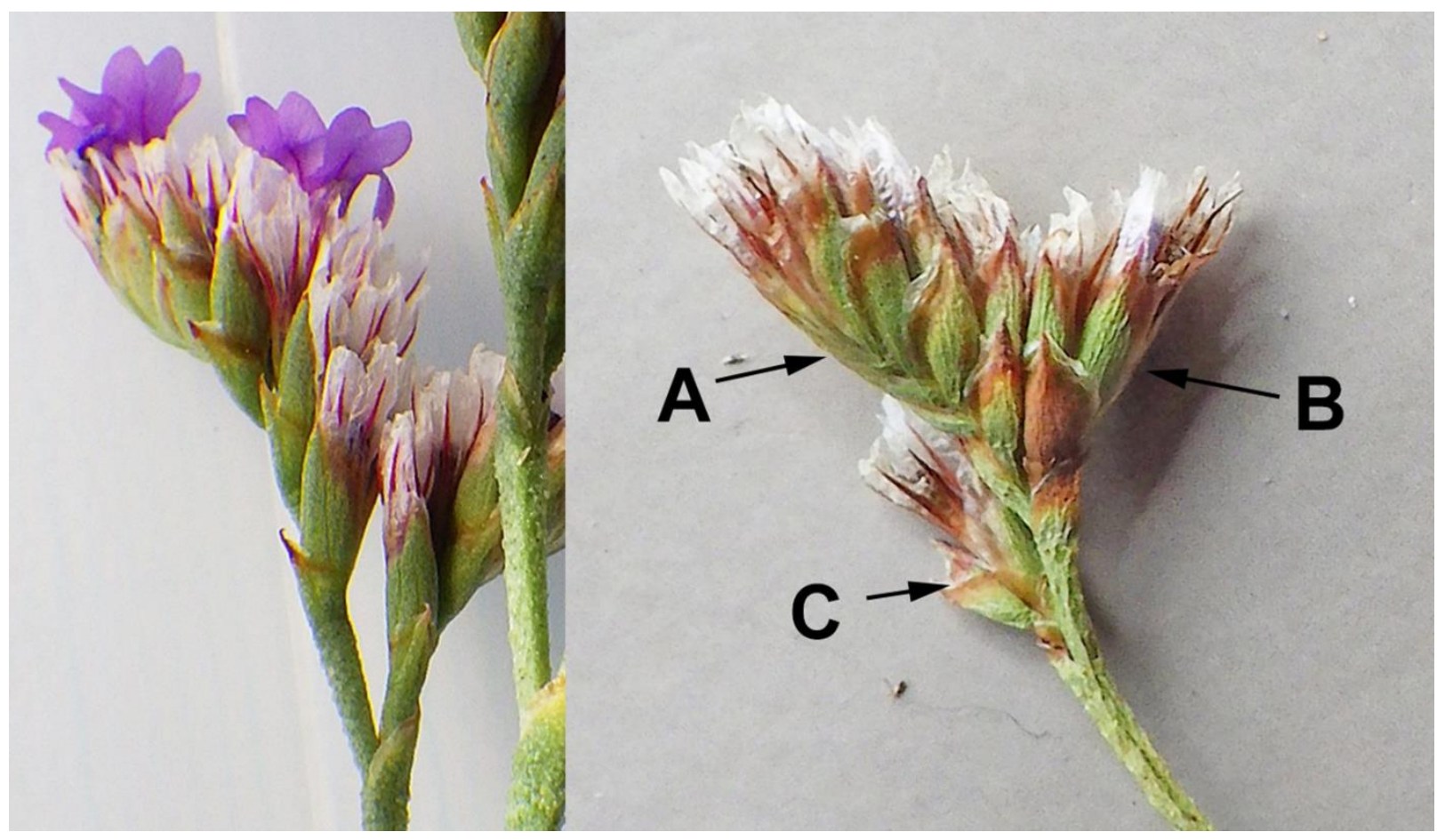

Figure 4. Left: terminal spike of Limonium recurvum subsp. crigyllensis on a major branch showing progressive greater cover of inner bract by outer in the sequence of spikelets and the aristate ribs on the calyces $07 / 2021$. Right: terminal spike (A) with partial extra branch (B) and small sub-terminal spike (C).

Outer bracts 3.0-4.0 $\mathrm{mm}$ with a hyaline margin to either side of a more robust median point, coloured brown near the tip and green elsewhere. Middle bracts 2.0$3.5 \mathrm{~mm}$. Inner bracts $5.0-6.0 \mathrm{~mm}$. On the larger recurved spikes, the outer bracts progressively cover more of the inner bract from the proximal to the distal spikelets (Fig. 4, left). Calyx 6.0 -7.2 mm, including the lobed hyaline margin. This is often subject to damage or loss after the short-lived corollas have shrunk or detached. The more robust pigmented tubular part of the calyx which remains is $5-7 \mathrm{~mm}$ long. This has prominent aristate, brown pigmented ribs (Fig. 4, left) with rows of microscopic upward pointing bristles at the base of the tube. Corollas have emarginate rounded lobes about $2.4 \mathrm{~mm}$ wide. Often there is a darker coloured stripe in the middle of the lower part of the corolla lobes. Styles are cob type. 


\section{Comparison with other Irish Sea taxa}

Using a biomolecular method, Cowan et al. (1999) showed that the L. recurvum group of segregants (sensu Ingrouille \& Stace, 1986) were well separated from a cluster containing most of the other $L$. binervosum agg. micro-taxa, including $L$. procerum. The distinctive "jizz", allowing the rough scape plants to be spotted from a distance at the Afon Crigyll site, before checking by feeling the stems, is in keeping with this.

The locations nearest to Anglesey with confirmed $L$. recurvum (sensu lato) segregants are the Mull of Galloway (v.c.74) and St Bees Head (v.c.70). Plants at these sites were referred to as $L$. recurvum subsp. humile var. humile (Girard) Ingrouille (Ingrouille \& Stace, 1986). After raising to species, they were re-named as L. naniforme Sell (Sell \& Murrell, 2018). Precedence for the L. recurvum name belongs to a Portland Bill segregant named by C.E. Salmon in 1903. In addition, Sell also gave the Mull of Galloway and St Bees taxon a different common name, as "Northern Sea-lavender", rather than "Irish Sea-lavender". "Irish" was instead applied to L. hibernicum (Ingr) P.D. Sell, formerly considered to be a subspecies of $L$. procerum and which is endemic on the east coast of Ireland. The type specimen of $L$. naniforme Sell had originally been collected from the Mull of Galloway as Statice dodartii var. humilis Girard. It is in BIRM and imaged on Herbaria@home (http://herbariaunited.org/atHome/). While fine details such as measurements of bracts cannot be made from the online image, there are differences between the Mull of Galloway type specimen and the Crigyll Estuary plants. This applies particularly to the proximity of principal / terminal and adjoining sub-terminal spikes. The type specimen does not show any extra spikes directly at the base of terminal spikes, as often seen on the Crigyll plants (Fig. 4, right). Instead, there is a clear separation between sub-terminal and terminal spikes. The terminal spikes also appear to have spikelets less tightly packed together in the Mull of Galloway specimen. The account of characteristic features of $L$. recurvum subsp. humile var. humile by Ingrouille \& Stace (1986) states that there are few sterile branches and that these are unbranched. By contrast, the Crigyll plants sometimes have more than one sterile branch and these may also branch.

Zooming in on photographs taken by Michael Jeeves (BSBI Vice-county Recorder for Wigtownshire, v.c.74) in July 2021 of Mull of Galloway cliff edge plants allows comparisons of the leaf characters of living plants. The Mull of Galloway photo (Fig. 5, right) shows leaves that were narrowly oblanceolate with a pronounced subacute apex and with salt glands prominent on the lamina surfaces. Amongst the herbarium sheets of Mull of Galloway L. recurvum in RBGE, one from 2010 is available online as a digital image. This also shows the rather strap like leaf shape. By contrast the Crigyll Estuary plants have leaves with an obtuse apex and some tend to be sub-spathulate. Salt glands are not prominent on leaves of Crigyll Estuary plants. Thus, on several characters the Crigyll Estuary plants are sufficiently different to consider them as a different micro-taxon from the Mull of Galloway. The Crigyll plants also differ in spike characters from ones on a sheet labelled as $L$. recurvum subsp. humile in the Lancaster University herbarium (transferred to Carlisle Museum). The St Bees plants mostly had spikes that were longer than those at the Mull of Galloway and Anglesey. 

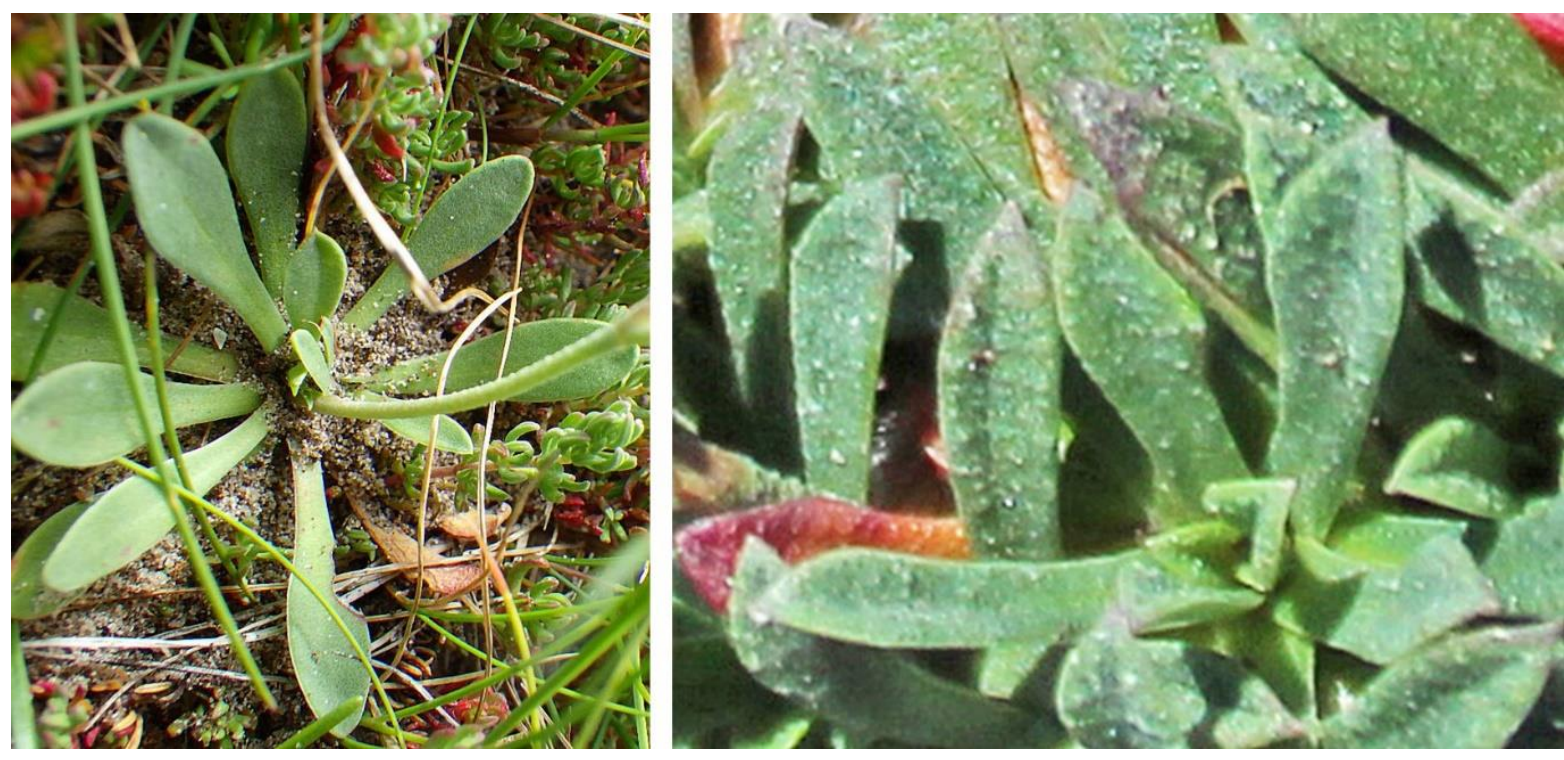

Figure 5. Comparison between (left) living rosette leaves of Anglesey Limonium recurvum subsp. crigyllensis and (right) Mull of Galloway $L$, recurvum subsp. humile (cropped from photo by M. Jeeves).

One feature mentioned by Ingrouille \& Stace (1986) as found in both $L$. recurvum subsp. pseudotranswallianum Ingrouille (from Co. Clare, v.c.H9) and $L$. recurvum subsp. humile was described as "outer bract coming to conceal inner bract towards the end of the spike". The Crigyll plants with outer bracts that progressively cover a greater proportion of the inner in sequence would fit this description (Fig. 4). In further comments Ingrouille \& Stace considered that subsp.

pseudotranswallianum was closer to the Donegal segregants than to others found further south on the west coast of Ireland and that the Donegal ones were related to the Mull of Galloway ones. Baker (1954) had also commented on similarities between Donegal and Mull of Galloway forms.

It is difficult to determine, just from morphology, which features may be genotypic and which may have been imposed by the environment. In the case of $L$. binervosum agg. in Britain \& Ireland, genotypic links are likely to reflect spread from glacial refugia, probably off the present coasts of Iberia, Biscay or the Western Mediterranean. The biomolecular evidence (Cowan et al, 1999) implies that the $L$. recurvum (sensu lato) line had probably separated much earlier. The hierarchical nomenclature system, such as that propounded by Ingrouille \& Stace (1986), has merit in that it tries to group similar segregants together in ways that possibly reflects former biogeographical links. The Crigyll rough scape plants clearly belong within a grouping of $L$. recurvum (sensu lato) micro-endemics. As mentioned above, closer examination may also show the St Bees plants differing in some respects from those at the Mull of Galloway. This would be consistent with the geographical separation of the two sites.

\section{Records from Anglesey earlier than 2006}

The Crigyll Estuary has been extensively colonised by Frankenia laevis which is not native on this coast. It was first noticed near Rhosneigr in 1965, but whether it got there accidentally or was introduced is unknown (Roberts, 1975). Due to this. the possibility that $L$. recurvum subsp. crigyllensis was also a recent arrival had to be 
considered. In the National Museum of Wales herbarium collection there is a sheet (NMW scanned image 0002213) collected by J.E. Griffith (1843-1933) which has two $L$. binervosum agg. plants on it. The upper one has zig-zag branching and recurved spikes strongly resembling $L$. recurvum subsp crigyllensis. The label indicates that it was collected on the west coast of Anglesey. It is not dated but there are other herbarium sheets by Griffith from Anglesey dated in the late 1880s. Griffith labelled it Limonium recurvum? A date slightly later than the 1880 s seems likely as C.E. Salmon (1872-1930) did not name L. recurvum (from Portland) until 1903. The same sheet also has a note by Salmon written on it expressing doubt that it was $L$. recurvum and implying that more samples were needed to make a determination. This can be interpreted as in Salmon's opinion the Griffith plant (or plants) differed from the $L$. recurvum at Portland. This would certainly apply to the small second plant on the same sheet which resembles more closely a diminutive segregant of unknown identity that was seen several times post 2000 at another restricted site on the west coast of Anglesey (a cove mid-way between Trearddur Bay and Rhoscolyn, SH259758). The Griffith sheet seems to provide evidence that there were plants resembling the newly described segregant somewhere on the west coast of Anglesey before 1930 and probably before 1910. There is another sheet in NMW (scanned image 0002205) collected by R.H. Roberts (1910-2003), labelled as $L$. binervosum, that has the characteristics of $L$. recurvum subsp. crigyllensis. The habitat and location is given as saltmarsh, Rhosneigr. There is no date of collection, but from the notes on the record cards from his time as BSBI Vice-county Recorder (now held by I.R. Bonner), and on one particular record in the BSBI Distribution Database (https://database.bsbi.org/), the most likely year of collection was 1987.

Contrary to the above, two other botanists with special knowledge of Limonium spp. are known to have visited the Crigyll locality, but without recording the distinctive rough scape plants. M.J. Ingrouille visited in July 1979 when collecting material for his research into the taxonomy of L. binervosum agg. (Ingrouille \& Stace, 1986). The 6-figure grid reference for the location where he took a sample of $L$. procerum is only a short distance along one of the main access paths. The lack of a record from 1979 seems more likely to have been due his visit being a brief stop on a tour to gather material from several places on Anglesey. H. Dawson, who was mainly studying the morphometrics of $L$. vulgare (Common Sea-lavender) and $L$. humile (Lax-flowered Sea-lavender), visited in August 1986, as evidenced by a sheet labelled as $L$. binervosum agg. in NMW. This has several $L$. procerum plants on it but none appearing to be $L$. recurvum subsp. crigyllensis. The grid reference given by Dawson was near to the Ingrouille position and again not far into the site. $L$. procerum was still frequent near these 1979 and 1986 positions in $2006-2021$.

Searches of Herbaria@home located a sheet in BIRM, labelled on the database as L. binervosum agg and said to be from Holyhead Mountain in 1921. The original collector, Rev. Douglas Montagu Heath, called it L. recurvum. There is a barely legible note on the sheet to the effect that he passed another "gathering" he made to someone else who then submitted it to experts (not named) who made a 
determination. The plant on this BIRM sheet certainly does not resemble $L$. recurvum subsp. crigyllensis.

\section{Other Irish Sea records with uncertain identity}

Away from Anglesey, there was a single record in 1987 from the coast of the Isle of Man (v.c.71). From details in the DDb, there were several plants in tide line turf at the top of rocks. The site was on a SW facing shore between Port St Mary and Castletown (National Grid monad SC2467). Plants were sent by D.E. Allen to M.J. Ingrouille who described it as a variant of $L$. recurvum and possibly a new subspecies. These plants have not been recorded subsequently and it is thought that the site was subject to coastal erosion.

Sell \& Murrell (2018), in the section on L. kerryensis (Ingr) P.D. Sell (Kerry Sealavender) (= L. recurvum subsp. portlandicum var. kerryense Ingrouille), wrote that "A specimen from near Dublin may be the same species". This implies there is another uncertain Irish Sea record of a $L$. recurvum (sensu lato) segregant, but the location of the specimen was not given. Finally, the record in the BSBI Database of L. recurvum from the north side of Morecambe Bay. near Ulverston (now Lancashire but in Watsonian v.c.69), is considered to have been a transcription error (M. Porter pers. comm.).

\section{Habitats, Distribution \& Abundance}

The Afon Crigyll enters the sea between the sand dunes of Tywyn Trewan on the southwest facing coast of Anglesey. Back from the beach the main channel meanders through a wider area of sand and sandy saltmarsh. The upper levels of marsh only flood when the biggest tides are amplified by storm surges. There are patches of relatively bare sandy gravel and it was on these that the best developed clumps of the rough scape plants were noticed in 2006. Since then, more of the area has developed closed grassy swards, with increasing cover also by Frankenia laevis.

Post-2010 more clumps of $L$. recurvum subsp. crigyllensis have also been found at strandline levels with Frankenia laevis, where dunes had been cut back by extreme tides (Fig. 6). In 2020 it was also noticed that some clumps of the rough scape Sea-lavender were associated with the sides of slight mounds, Woodell (1974) described an association between mounds created by the ant Lasius flavius and Frankenia laevis at Scolt, Norfolk. Mounds of apparently similar appearance occur in parts of the Crigyll Estuary and Sea-lavender scapes come up through the mass of flowering shoots of Frankenia laevis.

The total extent of the area within which L. recurvum subsp. crigyllensis occurs in the Crigyll Estuary is only about $600 \times 300 \mathrm{~m}$, but owing to the intersection of National Grid lines, the plants have been recorded in 4 tetrads (monads SH3173, $3174,3273 \& 3274$ ). This can give a misleading impression on atlas maps that they are more widespread than they really are. In this estuary, L. humile is frequent in the damper hollows and old meander channels. Together, $L$ humile and $L$. procerum seemed to account for most of the Limonium spp. present at the site in 2021, with subsp. crigyllensis comprising about one in ten of the clumps. 


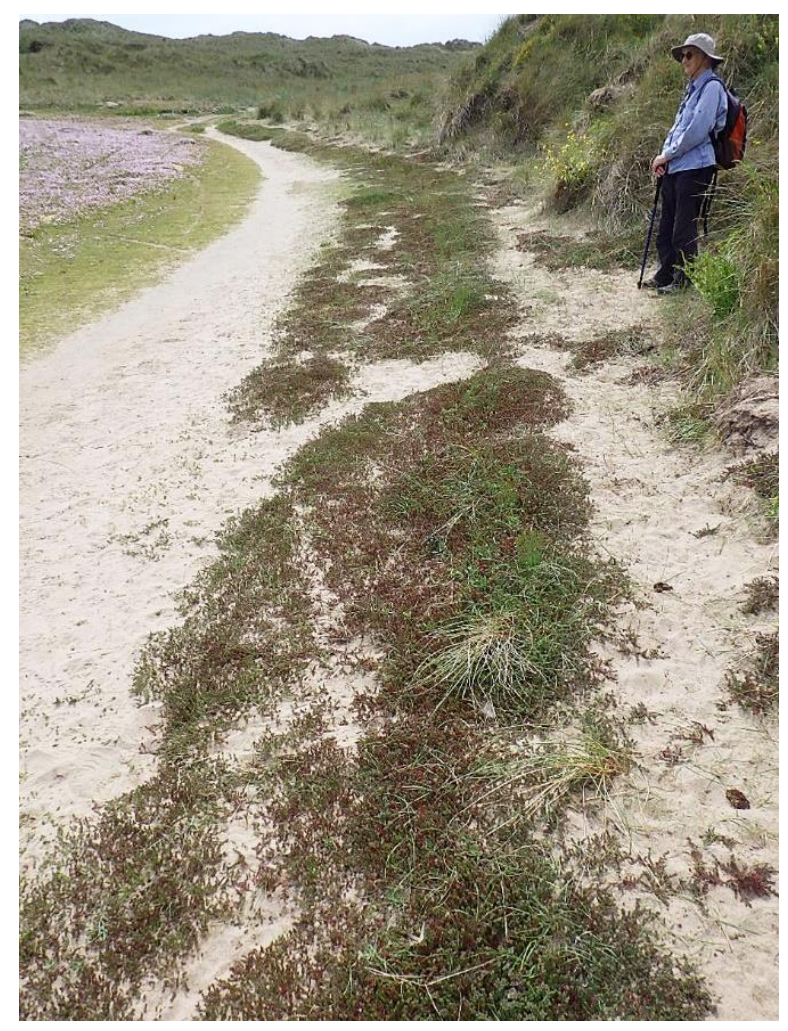

Figure 6. Ecotone strip of Frankenia laevis with L. recurvum subsp. crigyllensis growing within it, between saltmarsh and dunes SH317741, 19/06/2021.

\section{Colonisation, Change \& Conservation}

The Crigyll Estuary was visited by the author almost every summer between 2006, when $L$. recurvum (sensu lato) was noted, and 2021. Overall, the abundance at the site seems to have been relatively stable during these 16 years and rough scape plants were easily found on all visits. Individual clumps often have many rosettes connected to a deep root. and are long lived. This applies particularly to colonies in rocky habitats. Such plants seem to change very little over periods of years except with storm damage and regrowth. On the edges of sandy saltmarshes $L$. procerum has sometimes been noted to recruit abundant seedlings creating new patches, probably through tidal dispersal on extreme tides. The line of plants at the location shown in Fig. 6 seems to be an example of this in L. recurvum subsp. crigyllensis. The herbarium evidence that it was in the Crigyll Estuary two decades before 2006 and possibly more than seven decades earlier supports a conclusion that, whether introduced by man or arriving by natural means, it has not colonised the site in the last 100 years.

With any coastal plant having Lusitanian/Atlantic links and unexplained disjunct distributions, assisted dispersal in prehistoric times along the Western Maritime Highway can seldom be entirely distinguished from drift dispersal at some equally distant times in the Holocene. The extent to which disjunct distributions reflect erratic colonisation mediated by climate, or local extirpation as rising sea levels changed the coastline is an open question. A Limonium taxon with poor reproductive 
capabilities adapted to sandy sites with dynamic geomorphology might be more vulnerable than most to local extirpation.

On UK-wide Red Data Lists several of the micro-endemic L. binervosum agg. taxa have for many years been placed on Waiting Lists pending resolution of taxonomic questions. The GB Red Data List Group decided in 2021 to follow the Sell \& Murrell approach to microspecies, though there remained a lack of consensus on recognising quite so many taxa (Leach et al., 2021). The Group were also of the opinion that in most cases, those $L$. binervosum agg. forms that are highly restricted to small areas probably have populations that are large enough not to be threatened. This means that if placed in the Main List they would be categorised as LC (= least concern). Being endemic to such a small area $L$. recurvum subsp. crigyllensis would meet GB Red List criteria if treated as a full species. Restriction to high water levels could mean vulnerability to pollution incidents from the sea or the river. In the longer-term eutrophication and coastal squeeze with rising sea levels can be envisaged as risks. In an earlier Welsh List, Dines (2004) avoided the complexities of identification and taxonomy by lumping all the micro-endemics into the widespread L. binervosum agg.

\section{Acknowledgements}

Throughout investigations of Limonium taxa around Anglesey, Ian Bonner and James Robertson have provided much encouragement. Sally Whyman at National Museum of Wales helped greatly by locating relevant herbarium sheets and making high resolution scans. Michael Jeeves took a series of photos of the plants at Mull of Galloway for me. I am also grateful to G. Halliday, M. Porter and P. Tomlinson for providing information from various areas round the North Irish Sea and to Clive Stace for corrections in draft.

\section{References}

Baker, H.G. 1954. The Limonium binervosum complex in western and northern Ireland. Proceedings of the Botanical Society of the British Isles 1(2): 131141.

Cowan, R., Ingrouille, M.J. \& Lledo, M.D. 1998. The taxonomic treatment of agamosperms in the genus Limonium mill. (Plumbaginaceae). Folia Geobotanica 33: 353-366.

Dines, T. 2004. A Vascular Plant Red List for Wales. Plantlife Wales.

Ingrouille, M.J. \& Stace, C.A. 1986. The Limonium binervosum aggregate (Plumbaginaceae) in the British Isles. Botanical Journal of the Linnean Society 92: 177-217.

Jones, G.T. 1989. The Rivers of Anglesey. University College of North Wales, Bangor.

Leach, S.J. 2021. Vascular plant Red Data List for Great Britain: a summary of amendments in years 14 and 15 (2019-20) of the annual amendments process. BSBI News 147: 27-35.

Rees, E.I.S. 2010. Rock Sea-Lavender Limonium recurvum at Rhosneigr, Anglesey. BSBI NewS 113: 24-25.

Roberts, R.H. 1975. Frankenia laevis L. in Anglesey. Watsonia 19: 291-292.

Sell. P \& Murrell, G. 2018. Flora of Great Britain and Ireland. Volume 1, Lycopodiaceae - Salicaceae. Cambridge: Cambridge University Press. 
Stace, C.A. 1997. New Flora of the British Isles. $2^{\text {nd }}$ ed. Cambridge: Cambridge University Press.

Woodell, R.J. 1974. Anthill vegetation in a Norfolk saltmarsh. Oecologia 16: 223-226.

Copyright retained by author(s). Published by BSBI under the terms of the Creative Commons Attribution 4.0 International Public License.

ISSN: $2632-4970$

https://doi.org/10.33928/bib.2022.04.001 